\section{UNIVERSITIES OF THE BRITISH COMMONWEALTH}

The Yearbook of the Universities of the Commonwealth, 1949-50

Twenty-seventh issue. (Published for the Association of Universities of the British Commonwealth.) $\mathrm{Pp}$. xxxi+1367. (London: G. Bell and Sons, Ltd., 1950.)

$\mathrm{T}$

HE "Yearbook" was first published in 1914, and

this twenty-seventh issue which now supersedes that of 1948 is once more a mine of information. It is published by the Association of Universities of the British Commonwealth, and one of the first things that it records is the change that took place in 1948 whereby at an extraordinary general meeting the Association was given its new name in place of the old Universities Bureau of the British Empire.

The book covers the university institutions of the British Commonwealth (and also, "for historical reasons", those of the Republic of Eire), and the information is compiled from official lists obtained in the first place from the relevant institutions. The subject-matter is made up of a separate section on each country, each section being prefaced by a general introduction which contains a short history of the growth of university education in that country. Short notes on general information are appended to each institution, and, for the more recently founded, these notes include a brief historical résumé. A large proportion of the text is taken up with lists of the staff on the faculties of the various institutions, and this probably forms the most useful part of the book as a work of reference (and is the one which no doubt requires the most attention in preparing successive issues). The value of such staff lists is considerably enhanced by a name index, in addition to an ordinary general index.

Since the previous issue of 1948 , the Universities of Nottingham and Natal have received their charters, and the relevant details of these Universities have been published. The editor was unable to include details of the new University of Malaya, and it was not until the time of going to press that he received information regarding the new Universities of Poona and of Jammu and Kashmir.

The last part of the "Yearbook" consists of eight appendixes devoted to the following topies: (1) qualifications for admission to a first degree in the universities of Great Britain and Ireland; (2) the number of students from overseas in the universities and university colleges of Great Britain and Ireland ; (3) postgraduate scholarships and grants for advanced study and research, tenable in the United Kingdom ; (4) postgraduate scholarships and grants, etc., tenable outside the United Kingdom; (5) the composition of the Inter-University Council for Higher Education in the Colonies (which was created in 1946), and the terms of reference of the Council ; (6) universities of the United States (a very brief outline) ; (7) details of four appointments for the study of Anglo-American relations; (8) university admission from 1951, as a result of the fortheoming introduction of the General Certificate of Education (this appendix is a supplement to (1)). Of these appendixes, (2) is mainty a statistical analysis of the distribution of overseas students in Great Britain, and it gives the interesting facts that there are 7,960 such students $(4,311$ from the Commonwealth) made up as follows: Europe,
2,003 ; Asia, 1,974; Africa, 1,844 ; America, 1,488 ; Australasia, 635 ; stateless, 16.

The editor states that it is hoped to publish future issues during the first quarter of each year. In welcoming this present issue, we trust that the normal difficulties of publication which beset such an enterprise -apart from the special difficulties of the present day-will not hinder this admirable endeavour.

\section{THE ADRENAL GLAND IN MAMMALS}

The Mammalian Adrenal Gland

By Geoffrey H. Bourne. Pp. vii $+239+15$ plates. (Oxford: Clarendon Press ; London: Oxford University Press, 1949.) 30s. net.

A FAVOURITE gambit of lecturers is to tell A students that the amount of structural differentiation of the anterior part of the pituitary gland belies the organ's multiple functions. The position is rapidly becoming the same in the case of the adrenal. Dr. Bourne's attempt to enlarge our knowledge of the structure of the gland is therefore very timely. After an introductory chapter outlining the history of our knowledge of the subject, he takes the mammals in turn, and provides a statement about the structure of the adrenal in each of them. The observations on marsupials are mostly his own, whereas those which relate to the Eutheria are mainly a compilation of scanty statements that have appeared in the literature. The book ends with a chapter in which the author tries to derive some generalizations, and indulges in certain speculations. His main generalization is that the adrenals in most of the Eutheria are stable both in position and structure. In the marsupials they vary in both respects, while in the monotremes they are fairly constant in position but variable in structure.

None of these conclusions is very new. On other scores, too, the book leaves the reader unsatisfied. We are told, for example, that the right adrenal gland is immediately applied to the inferior vena cava in two species of marsupial, an anatomical arrangement which "makes it possible for the gland to secrete adrenalin instantaneously into the main blood stream without having to pass, as in most other mammals, along an adrenal vein. This should enable these animals to give a remarkably prompt response to any emergency." But the right adrenal vein is always very short, and it is very questionable whether the existence of, say, $\frac{1}{4}$ in. of venous channel would make the slightest difference to the speed of the organism's response to adrenalin. Dr. Bourne also seems confused when he considers the site of cellular proliferation in the cortex. One view is that new cells proliferate in each zone. Another is that they are added to the cortex by the division of cells between the glomerulosa and fasciculata, and that the new cells migrate inwards to the zona reticularis, where they die. Dr. Bourne starts by apparently favouring the first view, and ends by building speculations on the second.

But the real shortcoming of Dr. Bourne's book is that it is out of date. In a bibliography comprising 425 titles, only six deal with works as recent as 1940 , four with 1941, six with each year 1942, 1943 and 1944, five with 1945 and three with 1946 , while no subsequent year is mentioned at all. It contains no 